\title{
PENGARUH UKURAN PERUSAHAAN, TANGIBILITY ASSETS, DAN KEPEMILIKAN MANAJERIAL TERHADAP STRUKTUR MODAL PADA SUB SEKTOR RITEL
}

\author{
Ni Kadek Arie Oktaviantari ${ }^{1}$ \\ I Gde Kajeng Baskara ${ }^{2}$ \\ ${ }^{1,2}$ Fakultas Ekonomi dan Bisnis Universitas Udayana (Unud), Bali, Indonesia \\ E-mail: viantariokta@yahoo.co.id
}

\begin{abstract}
ABSTRAK
Struktur modal merupakan kombinasi atau bauran sumber pembayaran atau hutang jangka panjang. Struktur modal menunjukkan proporsi atas penggunaan utang untuk membiayai investasi perusahaan, sehingga dengan mengetahui struktur modal perusahaan, investor dapat mengetahui keseimbangan antara risiko dan tingkat pengembalian investasinya. Penelitian ini bertujuan untuk mengetahui signifikansi pengaruh ukuran perusahaan, tangibility assets, dan kepemilikan manajerial terhadap struktur modal pada perusahaan sub sektor Ritel di Bursa Efek Indonesia (BEI) periode 2013-2017. Pengumpulan data pada penelitian ini menggunakan metode observasi nonpartisipan, dimana peneliti dapat melakukan observasi sebagai pengumpulan data tanpa ikut terlibat dari fenomena yang diamati. Pengambilan sampel pada penelitian ini menggunakan metode sampling non probability, dengan teknik purposive sampling dimana pengambilan sampel menggunakan pertimbangan tertentu. Penelitian ini menggunakan data kuantitatif dan teknik analisis data yang digunakan adalah regresi linear berganda. Hasil penelitian menunjukkan bahwa ukuran perusahaan dan tangibility assets berpengaruh positif dan signifikan terhadap struktur modal, serta kepemilikan manajerial berpengaruh negatif dan signifikan terhadap struktur modal. Implikasi penelitian ini adalah bahwa sebaiknya perusahaan dan investor memerhatikan ketiga variabel yang digunakan pada penelitian ini sebagai dasar pertimbangan terkait struktur modal.
\end{abstract}

Kata kunci: struktur modal, ukuran perusahaan, tangibility assets, kepemilikan manajerial

\begin{abstract}
Capital structure is a combination or source of payment mixor long-term debt. Capital structure shows the proportion of the use of debt to finance the company's investment, so that by knowing the capital structure of the company, investors can find out the balance between the risk and return on investment.The objective of this research is to find influence signification of firm size, tangibility assets, and managerial ownership on capital structure in retail company at Indonesian Stock Exchange period 2013-2017. Data collection in this research using nonparticipant observation methods, researchers can make observations as data collection without getting involved from observed phenomena.Sampling in this research using non probability sampling technique, namely purposive sampling where sampling uses certain considerations. This research uses quantitative data and the data analysis technique used is multiple linear regression. The result of this research showed that firm size and tangibility assets has positive and significant effect to the capital structure, and managerial ownership has negative and significant effect to the capital structure.
\end{abstract}

Keywords: capital structure, firm size, tangibility assets, managerial ownership. 


\section{PENDAHULUAN}

Suatu perusahaan atau organisasi baik itu yang berskala besar maupun kecil, berorientasi profit atau non profit, dikelola pemerintah ataupun swasta, pasti menaruh perhatian yang besar pada bidang keuangan karena keberhasilan organisasi hampir sebagian besar sangat ditentukan oleh keputusan keuangan atau dengan kata lain masalah yang timbul dalam organisasi berimplikasi terhadap bidang keuangan (Wiagustini, 2014:5). Manajemen keuangan berhubungan dengan tiga aktivitas yaitu aktivitas penggunaan dana, aktivitas perolehan dana dan aktivitas pengelolaan dana. Keputusan yang diambil oleh manajer keuangan meliputi keputusan investasi, keputusan pendanaan, dan keputusan mengenai deviden (Sulindawati dkk., 2017:7).

Manajer adalah orang yang paling bertanggung jawab untuk menyiapkan laporan keuangan. Manajer memiliki kendali utama untuk integritas sistem akuntansi dan catatan keuangan yang digunakan untuk membuat laporan keuangan (Wiyadi et al., 2016). Keputusan yang terpenting yang diambil oleh manajer adalah keputusan pendanaan dimana keputusan pendanaan suatu perusahaan merupakan keputusan yang dilakukan oleh manajer keuangan yang berkaitan dengan bagaimana membiayai keputusan investasi yang akan dilakukan perusahaan (Wiagustini, 2014:234). Keputusan pengelolaan modal yang baik adalah apabila terjadi perimbangan antara modal asing dan modal sendiri atau modal yang berasal dari dalam perusahaan dan modal yang berasal dari luar 
perusahaan. Perimbangan antara modal sendiri dengan modal asing diistilahkan dengan struktur modal (Sulindawati dkk., 2017:111).

Keputusan pengelolaan modal yang baik adalah apabila terjadi perimbangan antara modal asing dan modal sendiri atau modal yang berasal dari dalam perusahaan dan modal yang berasal dari luar perusahaan. Perimbangan antara modal sendiri dengan modal asing inilah yang dinamakan dengan struktur modal (Sulindawati dkk., 2017:111). Struktur modal menentukan bagaimana perusahaan membiayai operasi dan pertumbuhannya dengan menggunakan berbagai sumber dana(hutang dan ekuitas) (Malinić et al., 2013). Menurut Kamaludin dan Indriani (2012:3017) struktur modal merupakan kombinasi atau bauran sumber pembayaran atau hutang jangka panjang. Berbeda dengan struktur keuangan yang merupakan kombinasi seluruh pembiayaan atau utang, antara lain hutang jangka panjang, hutang jangka pendek, saham preferen dan saham biasa. Oleh karena itu proxi yang digunakan dalam mengukur struktur modal adalah Long Term Debt to Equity Ratio (LTDER).

Kebijakan struktur modal akan terkait dengan suatu pertukaran (trade off) antara risiko dan return. Penggunaan lebih banyak utang akan meningkatkan risiko yang ditanggung oleh para pemegang saham, antara lain insolvabilitas, kenaikan suku bunga, dan financial distress. Terdapat beberapa faktor yang menjadi pertimbangan dalam mengambil keputusan tentang struktur modal, yaitu risiko bisnis, pertimbangan pajak, fleksibilitas keuangan, dan sikap manajemen. Risiko yang lebih tinggi cenderung akan menurunkan harga 
saham, sebaliknya ekspektasi tingkat pengembalian yang lebih tinggi akan menaikkan harga saham. Sehingga struktur modal yang optimal harus diupayakan agar tercapai suatu keseimbangan antara risiko dan pengembalian agar dapat memaksimalkan harga saham (Wiyono dan Kusuma, 2017:173).

Enam faktor yang mempengaruhi keputusan struktur modal, yaitu pertumbuhan penjualan, stabilitas penjualan, struktur aset, sifat manajemen, keadaan pasar modal, dan pajak (Musthafa, 2017:86). Menurut Kamaludin dan Indriani (2012:325) perusahaan sebelum mengambil keputusan struktur modal diperlukan beberapa pertimbangan yang matang. Terdapat 11 faktor yang umumnya dipertimbangkan keputusan struktur modal, yaitu stabilitas penjualan, struktur aset, leverage operasi, tingkat pertumbuhan, profitabilitas, pajak, pengendalian, sikap manajemen, sikap pemberi pinjaman dan lembaga penilai peringkat, kondisi pasar keuangan, dan fleksibilitas keuangan. Ukuran perusahaan juga merupakan faktor yang dapat mempengaruhi struktur modal, faktor lainnya yaitu struktur aset, profitabilitas, growth opportunity, dan risiko bisnis.

Variabel pertama yang diteliti pada penelitian ini adalah ukuran perusahaan karena variabel ini sering menjadi faktor penentu keberhasilan suatu perusahaan, dimana perusahaan dalam ukuran lebih besar dipandang lebih mampu menghadapi krisis dalam menjalankan usahanya. Perusahaan besar cenderung akan melakukan diversifikasi usaha lebih banyak dari pada perusahaan kecil. Oleh karena itu kemungkinan kegagalan dalam menjalankan usaha atau kebangkrutan akan lebih kecil (Dewi dan Badjra, 2014). Temuan ini konsisten dengan hasil penelitian dari 
Sheikh dan Wang (2011), Yousefzadeh (2014), Awan (2014), Alipour et al. (2015), Wasim et al. (2016), Shahar et al. (2016), Abdulla (2017), serta M’ng et al. (2017), menemukan bahwa ukuran perusahaan memiliki pengaruh secara positif terhadap struktur modal. Sementara itu hasil penelitian dari Yarram (2013) dan Wellalage dan Locke (2015), menemukan bahwa ukuran perusahaan memiliki pengaruh secara negatif terhadap struktur modal.

Variabel kedua yang diteliti pada penelitian ini adalah struktur aset (tangibility asset). Variabel ini berhubungan dengan variabel pertama, dimana semakin besar perusahaan maka semakin besar pula aktivanya. Perusahaan yang memiliki aset tetap dalam jumlah yang besar dapat menggunakan hutang dalam jumlah yang besar, hal ini disebabkan perusahaan dengan skala aktiva tetap dapat dijadikan jaminan, sehingga lebih mudah memperoleh akses sumber dana (Kamaludin dan Indriani, 2012:325).Penelitian lain yang konsisten dengan temuan ini adalah Ramaratnam dan Jayaraman (2013), Wijaya dan Utama (2014), Wellalage et al. (2015), Shahar et al. (2016), Abdulla (2017), M'ng et al. (2017), dan yang terbaru oleh Tijow (2018) dimana tangibility assets mempunyai pengaruh secara positif terhadap struktur modal. Sementara itu pendapat lain dikemukakan oleh beberapa peneliti diantaranya,Sheikh dan Wang (2011), Yarram (2013), Malinić et al. (2013), serta Wasim et al. (2016) menemukan bahwa tangibility assets mempunyai pengaruh secara negatif terhadap struktur modal.

Variabel ketiga dalam penelitian ini adalah kepemilikan manajerial. Struktur kepemilikan cenderung memengaruhi biaya agensi. Ada kemungkinan saling 
ketergantungan antara struktur modal dan struktur kepemilikan, mengingat konflik kepentingan antara pemegang saham dan pemegang obligasi(Yarram, 2013).Pemberian kesempatan manajer untuk terlibat dalam kepemilikan saham bertujuan untuk menyetarakan kepentingan manajer dengan pemegang saham. Keterlibatan manajer tersebut mendorong manajer untuk bertindak secara hati-hati karena mereka akan turut menanggung konsekuensi atas keputusan yang diambilnya. Selain itu, manajer akan termotivasi untuk meningkatkan kinerjanya dalam mengelola perusahaan (Dewi, 2008).Kepemilikan manajerial merupakan tingkat kepemilikan saham oleh pihak manajemen yang secara aktif ikut dalam pengambilan keputusan (Wahidahwati, 2002).

Hasil penelitian dari Yarram (2013), kepemilikan manajerial mempunyai pengaruh secara positif terhadap struktur modal. Sementara itu menurut Wellalage dan Locke (2015), Primadhanny (2016), Siromi dan Chandrapala (2017),dan Munandar (2017) menemukan bahwa kepemilikan manajerial berpengaruh negatif terhadap struktur modal. Terdapat inkonsistensi temuan dari hasil penelitian di atas, maka hal ini menjadi celah penelitian yang menarik untuk dikaji ulang dengan tujuan memperjelas kemana arah penelitian tersebut.

Jumlah perusahaan atau emiten sub sektor ritel di BEI sebanyak 25 perusahaan, yang digunakan sebagai bahan penelitian dengan periode tahun 20132017. Sub sektor perusahaan ritel dipilih sebagai populasi penelitian karena perusahaan sub sektor ritel memiliki komposisi struktur aset berbeda dengan sub sektor lain, misal sub sektor keuangan. Dari hasil penelitian jumlah emiten pada sub sektor ini memenuhi standar penelitian dan konsisten dalam memberikan 
laporan keuangan serta terdapat data kepemilikan manajerial yang melengkapi data penelitian.

Menurut Ketua Umum Asosiasi Pengusaha Ritel Indonesia (Aprindo) ritel merupakan industri yang strategis di hilir karena 56 persen dari pertumbuhan ekonomi yang diharapkan pemerintah itu asalnya dari konsumsi rumah tangga. Ekspor masih rendah, investasi cukup baik, tapi 56 persen tetap dari konsumsi. Meskipun selama dua tahun terakhir ini industri ritel mengalami penurunan akibat beberapa hal seperti melemahnya konsumsi masyarakat dan melemahnya harga komoditas tetapi diperkirakan pertumbuhan industri ritel tahun 2018 ini bisa mencapai 10 persen karena ada tiga event besar yang akan meningkatkan konsumsi ritel, yaitu Pemilihan Kepala Daerah, Asian Games, serta IMF-World Bank Meeting. Data lain menunjukkan berdasarkan hasil survei yang dilakukan oleh perusahaan konsultan manajemen global dalam laporan Global Retail Development Index (GRDI), di mana laporan ini menilai kondisi industri ritel di 30 negara berkembang di dunia. Indonesia pada tahun 2017 berada di urutan kedelapan, dimana urutan pertama di tempati oleh India, kemudian China, Malaysia, Turki, Arab, Vietnam dan Moroko sebagai negara yang memiliki pertumbuhan bisnis ritel terbaik di kawasan Asia (ATKearney.com).

Lembaga survei The Nielsen Company Indonesia menyebut pertumbuhan sektor ritel mulai mengalami perbaikan pada dua bulan belakangan ini. Padahal pada kuartal I-2018 ritel hanya tumbuh sekitar 1 persen-1,5 persen. Menurut CEIC Data pertumbuhan Penjualan Ritel Indonesia dilaporkan sebesar 6,8 persen pada bulan Juni 2018. Rekor ini turun dibanding sebelumnya yaitu 
8,3 persen di bulan Mei 2018. Data pertumbuhan penjualan ritel Indonesia diperbarui bulanan, dengan rata-rata 10,6 persen dari tahun 2011 sampai bulan Juni 2018, dengan 90 observasi. Data ini mencapai angka tertinggi sebesar 28,2 persen pada bulan desember 2013 dan rekor terendah sebesar $-5,9$ persen. Menurut laporan BEI, pada tahun 2017 pasar modal dalam negeri mencatat rekor tertinggi dalam hal kapitalisasi pasar, yakni sekitar Rp 7.052 triliun. Begitu pula indeks pasar sebesar $6.355,65$ poin, transaksi pasar dari segi volume (11,95 miliar unit saham per hari), nilai ( $\operatorname{Rp~7,6~triliun~per~hari),~maupun~}$ frekuensi perdagangan yang sebanyak 312,48 ribu kali transaksi (ceicdata.com). Menurut Mantan Direktur Utama BEI keberhasilan capaian tersebut antara lain dipicu oleh ekspansi basis investor ritel domestik. Dilansir dari Kontan.co.id bahwa saham sub sektor ritel masih akan menjadi pilihan investasi menarik tahun 2018 dimana tahun ini daya beli masyarakat diekspektasikan meningkat sehingga minat masyarakat cenderung lebih besar. Menurut analis Paramita Alfa Sekuritas William Siregar, bahwa Bank Indonesia dalam risetnya mengatakan bahwa indeks ekspektasi konsumen masih stabil dan hal tersebut punya pengaruh yang cukup besar bagi kinerja sub sektor keuangan dan juga ritel.Secara umum terdapat beberapa teori yang membahas struktur modal, yaitu: Balancing theories biasa disebut teori keseimbangan karena tujuannya adalah untuk menyeimbangkan komposisi hutang dan modal sendiri. Teori ini dapat diterapkan pada kondisi pasar modal yang sempurna dan tidak ada pajak serta kondisi pasar modal sempurna dan ada pajak. Struktur modal pada pasar yang sempurna dan tidak ada pajak memiliki dua pendekatan, yaitu:Pendekatan Tradisional. Mereka yang menganut 
pendekatan tradisional berpendapat bahwa keadaan perusahaan menjadi lebih baik setelah perusahaan menggunakan hutang karena nilai perusahaan meningkat (atau biaya modal perusahaan menurun).

Pendekatan Modigliani dan Miller

Pendekatan ini membantah pendekatan tradisional karena dalam keadaan pasar modal sempurna dan tidak ada pajak, maka keputusan pendanaan (financing decisions) menjadi tidak relevan. Artinya penggunaan utang atau modal sendiri akan memberi dampak yang sama bagi kemakmuran pemilik perusahaan (Husnan, 2013:323).

Bentuk risiko yang harus ditanggung perusahaan dalam balancing theories, yaitu:Jika perusahaan meminjam dana ke perbankan, maka dibutuhkan jaminan atau agunan seperti tanah, gedung, kendaraan, dan sejenisnya. Jika perusahaan terlambat membayar maka akan diberikan teguran baik lisan maupun tulisan, sementara jika perusahaan tidak mampu lagi membayar angsuran di atas batas waktu yang ditentukan maka agunan tersebut diambil dan dilelang oleh perbankan untuk menutupi kerugian sejumlah nilai pinjaman. Artinya perusahaan telah kehilangan aset yang diagunankan tersebut, jika kebutuhan dana dengan cara menjual obligasi, bentuk risiko yang dihadapi adalah jika seandainya tidak sanggup membayar bunga obligasi secara tepat waktu atau bergeser dari waktu yang disepakati maka perusahaan harus melakukan berbagai kebijakan untuk mengatasinya, termasuk mengkonversi dari pemegang obligasi ke pemegang saham. 
Risiko selanjutnya terhadap masalah yang dialami oleh perusahaan tersebut adalah telah menyebabkan nilai perusahaan di mata publik terjadi penurunan, karena publik menilai kinerja keuangan perusahaan tidak baik khususnya dalam kemampuan manajemen struktur modal (capital structure management) (Fahmi, 2016:193).

Pecking Order Theory dikemukakan oleh Myers dan Majluf, dimana teori ini mencoba menjelaskan keputusan pendanaan yang diambil oleh perusahaan yang berbeda dengan pemikiran teori struktur modal balancing theories (Husnan, 2013:324). Pecking order theory merupakan suatu kebijakan yang ditempuh oleh suatu perusahaan untuk mencari tambahan dana dengan cara menjual aset yang dimilikinya. Seperti menjual gedung, tanah, peralatan, yang dimilikinya dan asetaset lainnya, termasuk dana yang berasal dari laba ditahan (retained earnings) (Fahmi, 2016:194).

Trade-off theory merupakan struktur modal yang menyatakan bahwa perusahaan menukar manfaat pajak dari pendanaan utang dengan masalah yang ditimbulkan oleh potensi kebangkrutan (Brigham dan Houston, 2011:183). Pada teori ini, dilakukan pertukaran manfaat pajak dengan potensi kebangkrutan yaitu apabila perusahaan mengharapkan laba yang besar sebagai akibat penghematan pajak, maka akan menerima risiko biaya dari potensi kebangkrutan.

Tujuan dari perusahaan adalah memaksimalkan kekayaan dari pemegang saham. Kenyataannya manajemen perusahaan diberikan kekuasaan oleh pemegang saham untuk mengambil keputusan yang dapat mengambil konflik kepentingan yang disebut dengan teori agensi atau agency theory. 
Penelitian ini bertujuan untuk mengetahui pengaruh ukuran perusahaan, tangibility assets, dan kepemilikan manajerial terhadap struktur modal. Kontribusi dari penelitian ini memberikan bukti empiris mengenai pengaruh ukuran perusahaan, tangibility assets, dan kepemilikan manajerial terhadap struktur modal dan memberikan informasi tambahan serta bahan pertimbangan dalam mengambil keputusan pendanaan yang terkait dengan struktur modal pada perusahaan sub sektor ritel di Bursa Efek Indonesia.

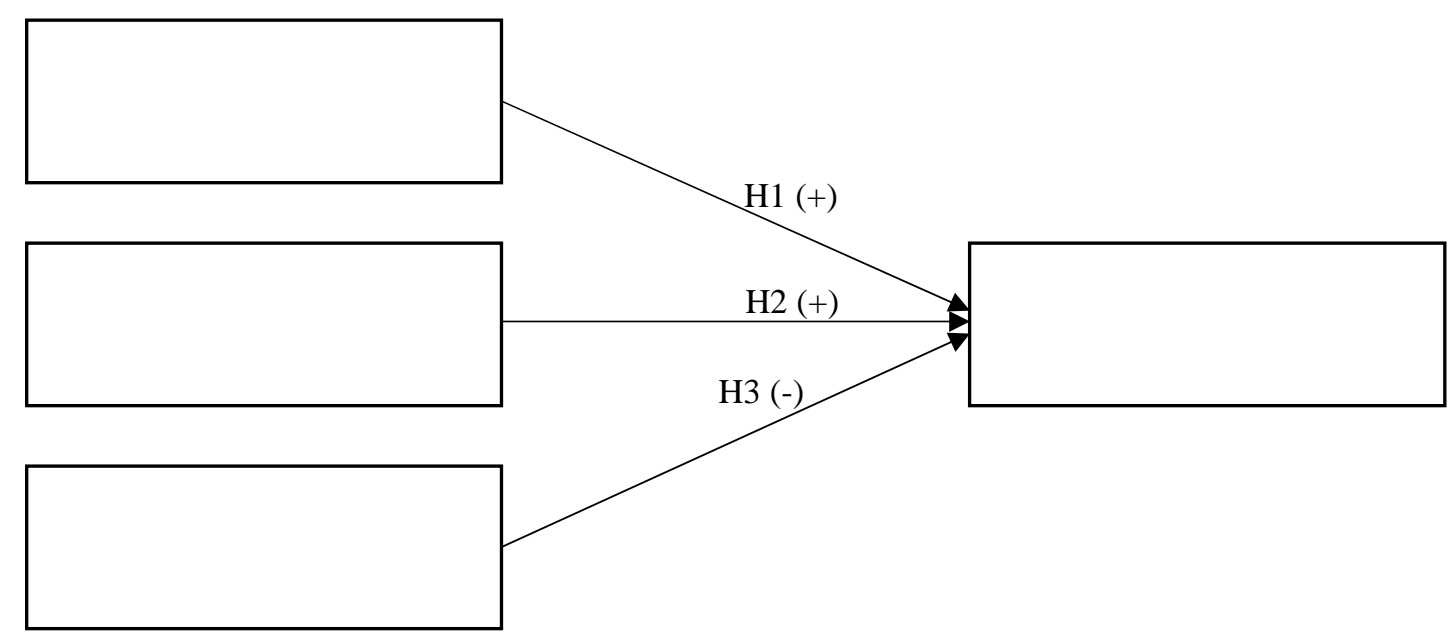

\section{Gambar 1.Kerangka Konseptual Penelitian}

Struktur modal merupakan kombinasi antara hutang dan modal sendiri, dimana untuk memperoleh modal yang dibutuhkan perusahaan perlu memperhitungkan perimbangan antara hutang dan modal (Wiyono dan Kusuma, 2017:173). Pada penelitian kali ini variabel struktur modal akan diukur dengan menggunakan Long Term Debt to Equity Ratio (LTDER) yang membandingkan hutang jangka panjang yang dimiliki perusahaan dengan total modal sendiri perusahaan dari tahun 2013-2017 pada sektor ritel di Bursa Efek Indonesia (BEI). 
Long Term Debt to Equity Ratio (LTDER) dinyatakan dalam persentase dengan rumus sebagai berikut (Wiagustini, 2014:88)

Long Term Debt to Equity Ratio $=$\begin{tabular}{llll}
$\mathrm{H}$ & $\mathrm{F}$ & $\mathrm{P}$ \\
\hline $\mathrm{T}$ & $\mathrm{M}$ & $\mathrm{S}$
\end{tabular} $\mathrm{x}=00 \%$

Ukuran perusahaan merupakan cerminan total aset yang dimiliki perusahaan. Ukuran suatu perusahaan dalam penelitian ini dapat dihitung dengan logaritma natural dari total assets pada perusahaan sub sektor riteldi BEI periode 2013-2017 dimana dinyatakan dengan rumus sebagai berikut (Andrayani dan Sudirman, 2014).

Ukuran $\quad$ Perusahaan Ln $\quad$ (total assets)

Tangibility Assets merupakan aktiva tetap yang digunakan untuk operasional perusahaan, bentuk kekayaan tersebut berupa aset-aset tetap atau berwujud yang ada di perusahaan. Penelitian kali ini akan dilakukan di perusahaan sub sektor ritel di BEI periode 2013-2017. Tangibility Assets dapat dihitung menggunakan rumus sebagai berikut (Andrayani dan Sudirman, 2014).

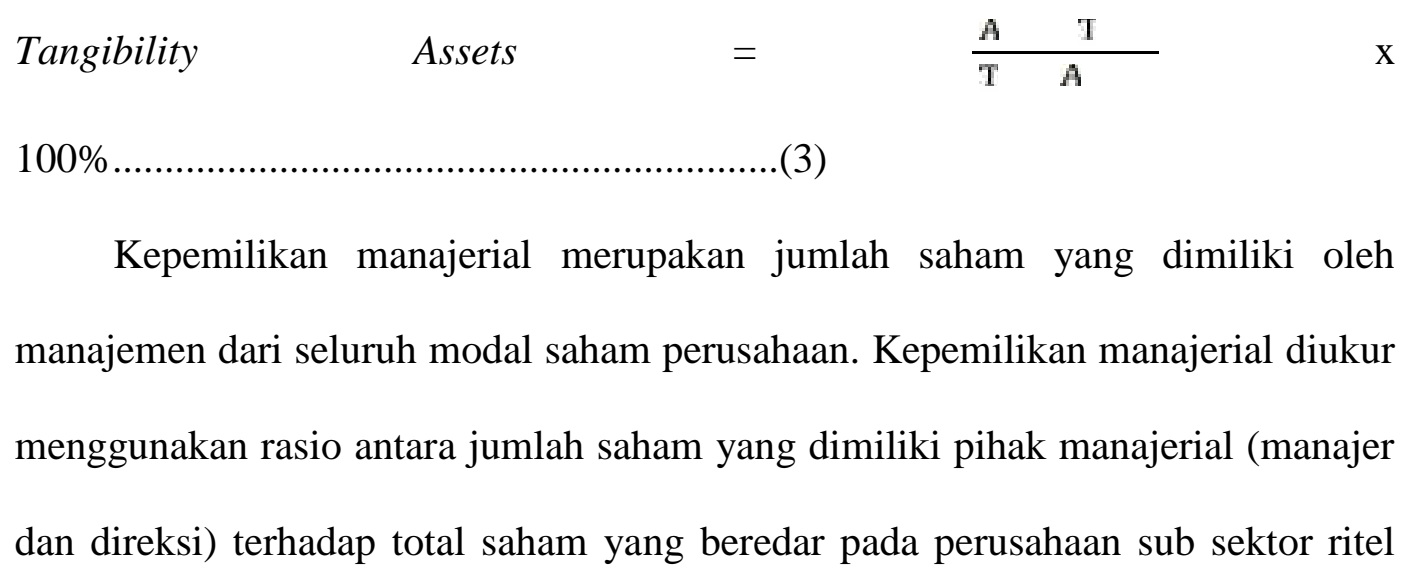


yang terdaftar di BEI periode 2013-2017. Satuan kepemilikan manajerial adalah persen. Rumusnya dapat diformulasikan sebagai berikut (Farooque et al., 2007).

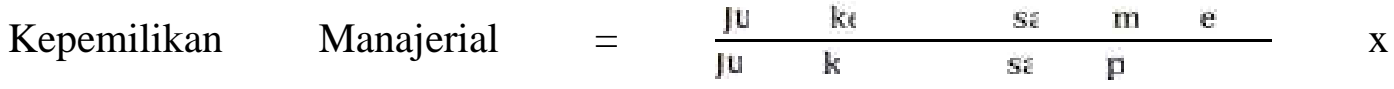
100persen

Semakin besar suatu perusahaan maka kecenderungan penggunaan dana eksternal juga akan semakin besar (Manopo, 2013).Hal ini didukung dengan penelitian terbaru yang dilakukan oleh M'ng et al. (2017), Abdulla (2017), Shahar et al. (2016),Wasim et al. (2016),Alipour et al.(2015), Awan (2014), Dewi dan Badjra (2014),Yousefzadeh (2014), Indrajaya dkk. (2011), serta Sheikh dan Wang (2011), yang menemukan bahwa ukuran perusahaan berpengaruh positif terhadap struktur modal.

$\mathrm{H}_{1}$ : Ukuran perusahaan berpengaruh secara positif dan signifikan terhadap struktur modal perusahaan.

Perusahaan yang struktur asetnya memiliki perbandingan aktiva tetap jangka panjang lebih besar akan menggunakan hutang jangka panjang lebih banyak karena aktiva tetap yang ada dapat digunakan sebagai jaminan hutang (Brigham dan Houston, 2011:188).Hal ini didukung dengan penelitian terbaru oleh Tijow dkk. (2018), Abdulla (2017), Shahar et al. (2016), Wellalage dan Locke (2015), Dewi dan Badjra (2014), serta Ramaratnam dan Jayaraman (2013) yang menemukan bahwa tangibility assets berpengaruh positif terhadap struktur modal.

$\mathrm{H}_{2}$ : Tangibility assets berpengaruh secara positif dan signifikan terhadap struktur modal perusahaan. 
Menurut Primadhanny (2016) menemukan bahwa kepemilikan manajerial memiliki pengaruh secara negatif dan signifikan terhadap struktur modal, dimanaketika kepemilikan manjerial naik, maka struktur modal perusahaan akan menurun. Temuan ini konsisten dengan penelitian terbaru oleh Munandar (2017),Siromi dan Chandrapala (2017), serta mendukung penelitian sebelumnya oleh Wellalage dan Locke (2015) yang menemukan bahwa kepemilikan manajerial memiliki pengaruh yang negatif terhadap struktur modal.

$\mathrm{H}_{3}$ : Kepemilikan manajerial berpengaruh negatif signifikan terhadap struktur

modal.

\section{METODE PENELITIAN}

Metode pengumpulan data yang digunakan pada penelitian ini adalah metode observasi nonpartisipan, dimana peneliti dapat melakukan observasi sebagai pengumpulan data tanpa ikut terlibat dari fenomena yang diamati (Sugiyono, 2017:166). Penelitian ini menggunakan pendekatankuantitatif dengan desain asosiatif. Penelitian ini dilakukan pada perusahaan sub sektor ritel yang terdaftar di Bursa Efek Indonesia (BEI) periode 2013 - 2017. Obyek dari penelitian ini yaitu Struktur Modal Perusahaan Sub Sektor Ritel di Bursa Efek Indonesia periode 2013-2017. Variabel dalam penelitian ini adalah struktur modal sebagai variabel terikat dan variabel bebasnya adalah ukuran perusahaan, tangibility assets, dan kepemilikan manajerial. Populasi pada penelitian ini adalah perusahaan sub sektor ritel yang terdaftar pada Bursa Efek Indonesia periode 2013-2017 yang berjumlah 25 perusahaan. 
Tabel 1.

Daftar Perusahaan Sub Sektor Ritel Di Bursa Efek Indonesia

\begin{tabular}{|c|c|c|c|}
\hline No & Kode Saham & Nama Emiten & Tanggal IPO \\
\hline 1 & ACES & Ace Hardware Indonesia Tbk & 6 November 2007 \\
\hline 2 & AMRT & Sumber Alfaria Trijaya Tbk & 15 Januari 2009 \\
\hline 3 & CENT & $\begin{array}{l}\text { Centratama Telekomunikasi Indonesia } \\
\text { Tbk }\end{array}$ & 1 November 2001 \\
\hline 4 & CSAP & Catur Sentosa Adiprana Tbk & 12 Desember 2007 \\
\hline 5 & DAYA & Duta Intidaya Tbk & 28 Juni 2016 \\
\hline 6 & ECII & Electronic City Indonesia Tbk & 3 Juli 2013 \\
\hline 7 & ERAA & Erajaya Swasembada Tbk & 14 Desember 2014 \\
\hline 8 & GLOB & Global Teleshop Tbk & 10 Juli 2012 \\
\hline 9 & GOLD & Golden Retailindo Tbk & 7 Juli 2010 \\
\hline 10 & HERO & Hero Supermarket Tbk & 2 Desember 1989 \\
\hline 11 & KIOS & Kioson Komersial Indonesia Tbk & 5 Oktober 2017 \\
\hline 12 & KOIN & Kokoh Inti Arebama Tbk & 9 April 2008 \\
\hline 13 & LPPF & Matahari Department Store Tbk & 9 Oktober 1989 \\
\hline 14 & MAPI & Mitra Adiperkasa Tbk & 10 November 2004 \\
\hline 15 & MCAS & M Cash Integrasi Tbk & 1 November 2017 \\
\hline 16 & MIDI & Midi Utama Indonesia Tbk & 30 November 2010 \\
\hline \multicolumn{4}{|c|}{$\begin{array}{l}\text { Bersambung.. } \\
\text { Lanjutan tabel no. } 1\end{array}$} \\
\hline No & Kode Saham & Nama Emiten & Tanggal IPO \\
\hline 17 & MKNT & Mitra Komunikasi Nusantara Tbk & 26 Oktober 2015 \\
\hline 18 & MPPA & Matahari Putra Prima Tbk & 21 Desember 1992 \\
\hline 19 & RALS & Ramayana Lestari Sentosa Tbk & 24 Juli 1996 \\
\hline 20 & RANC & Supra Boga Lestari Tbk & 7 Juni 2012 \\
\hline 21 & RIMO & Rimo International Lestari Tbk & 10 November 2000 \\
\hline 22 & SKYB & Skybee Tbk & 7 Juli 2010 \\
\hline 23 & SONA & Sona Topas Tourism Industry Tbk & 12 Juli 1992 \\
\hline 24 & TELE & Tiphone Mobile Indonesia Tbk & 12 Januari 2012 \\
\hline 25 & TRIO & Trikomsel Oke Tbk & 14 April 2009 \\
\hline
\end{tabular}

Sumber: sahamok.com, 2017

Pengambilan sampel pada penelitian ini menggunakan teknik sampling non probability, yaitu purposive sampling. Purposive sampling adalah teknik pengambilan sampel sumber data dengan pertimbangan tertentu (Sugiyono, 2017:144). Sampel yang digunakan pada penelitian kali ini menggunakan beberapa kriteria.

Tabel 2.

Seleksi Sampel Berdasarkan Kriteria

Kriteria Ju


Perusahaan sub sektor ritel yang tidak memiliki data keuangan lengkap di

Bursa Efek Indonesia

Perusahaan sub sektor ritel yang tidak memiliki data lengkap terkait variabel penelitian

Sumber: idx.co.id, 2018

Berdasarkan kriteria yang telah diterapkan, dari 25 perusahaan sebagai populasi hanya 6 perusahaan yang sesuai dijadikan sebagai sampel penelitian.

Jenis data yang digunakan dalam penelitian ini ada 2 yaitu data kuantitatif dan data kualitatif. Data kuantitatif dari penelitian ini adalah laporan keuangan tahunan. Data kualitatif dari penelitian ini adalah daftar perusahaan sub sektor ritel yang aktif dalam perdagangan saham dan gambaran umum perusahaan sub sektor ritel. Sumber data yang digunakan pada penelitian ini adalah data sekunder.

Teknik analisis yang digunakan dalam penelitian ini adalah teknik analisis linear berganda dengan tujuan untuk melihat pengaruh dari tiga variabel bebas terhadap variabel terikat pada penelitian ini. Informasi mengenai variabel-variabel pada penelitian ini terkait rata-rata, nilai minimum, nilai maksimum, dan standar deviasi akan dijelaskan melalui analisis statistik deskriptif. Sebelum melakukan uji analisis regresi linear berganda, maka dilakukan uji asumsi klasik terlebih dahulu. Tujuan dari uji asumsi klasik ini adalah untuk memastikan bahwa model yang diperoleh benar-benar memenuhi asumsi dasar dalam analisis regresi yang 
meliputi asumsi tidak terjadi autokorelasi, tidak terjadi multikolineritas, dan tidak terjadi heteroskedastisitas.

\section{HASIL DAN PEMBAHASAN}

Tabel 3.

Hasil Statistik Deskriptif

\begin{tabular}{lccccc}
\hline \multicolumn{1}{c}{ Variabel } & N & Minimum & Maksimum & Mean & $\begin{array}{c}\text { Standar } \\
\text { Deviasi }\end{array}$ \\
\hline Struktur Modal & 30 & 0,018 & 1,325 & 0,260 & 0,324 \\
Ukuran Perusahaan & 30 & 13,476 & 15,999 & 14,937 & 0,715 \\
Tangibility Assets & 30 & 0,043 & 0,346 & 0,208 & 0,093 \\
Kepemilikan & 30 & 0,000 & 0,079 & 0,019 & 0,024 \\
Manajerial & & & & & \\
\hline
\end{tabular}

Sumber: Data diolah, 2018

Tabel 3 menunjukkan hasil uji statistik deskriptif dari variabel yang digunakan pada penelitian sebagai berikut.

Variabel Struktur Modal tertinggi dimiliki oleh PT Midi Utama Indonesia Tbk. pada periode 2017 sebesar 1,325persen dan nilai terendahnya dimiliki oleh PT Erajaya Swasembada Tbk. pada periode 2013 sebesar 0,018persen. Nilai ratarata struktur modal selama tahun 2013 hingga 2017 adalah sebesar 0,260persen dan standar deviasinya sebesar 0,324persen.

Variabel Ukuran Perusahaan tertinggi sebesar Rp 15,999 yang dimiliki oleh PT Erajaya Swasembada Tbk. pada tahun 2017 dan nilai terendah sebesar Rp 13,476 yang dimiliki oleh PT Supra Boga Lestari Tbk. pada tahun 2013. Nilai mean dari variabel ukuran perusahaan selama tahun 2013-2017 adalah sebesar Rp 14,937 dan standar deviasi yaitu sebesar Rp 0,715. 
Variabel Tangibility Assets tertinggi yaitu sebesar 0,346persen yang dimiliki oleh PT Supra Boga Lestari Tbk. pada tahun 2014 dan yang terendah dimiliki oleh PT Erajaya Swasembada Tbk. tahun 2013 sebesar 0,043persen. Nilai rata-rata untuk variabel tangibility assets tahun 2013 sampai 2017 adalah sebesar 0,208persen dan standar deviasinya sebesar 0,093persen.

Variabel Kepemilikan Manajerial tertinggi dimiliki oleh PT Ramayana Lestari Sentosa Tbk. sebesar 0,079persen dan terendah dimiliki oleh PT Ace Hardware Indonesia Tbk. sebesar 0,000persen. Nilai rata-rata dari variabel kepemilikan manajerial adalah sebesar 0,019persen dan untuk standar deviasi yaitu sebesar 0,024persen.

Hasil Kolmogrov-Smirnov sebesar 0,806 dan hasil Asymp. Sig. (2-tailed) sebesar 0,534. Ini berarti persamaan regresi dari penelitian ini berdistribusi normal karena nilai Asymp. Sig. (2-tailed) lebih besar dari nilai alpha0,05.

Tabel 4.

Hasil Uji Multikolinearitas

\begin{tabular}{ccc}
\hline \multicolumn{1}{c}{ Model } & \multicolumn{2}{c}{ Collinearity Statistic } \\
& Tolerance & VIF \\
\hline Ukuran Perusahaan & 0,485 & 2,062 \\
Tangibility Assets & 0,467 & 2,140 \\
Kepemilikan Manajerial & 0,750 & 1,333 \\
\hline Sumber: Data diolah, 2018 & \multicolumn{2}{c}{}
\end{tabular}

Nilai dari tolerance dan VIF pada variabel ukuran perusahaan, tangibility assets, dan kepemilikan manajerial menunjukkan bahwa model persamaan regresi bebas dari multikolinearitas. Pada tabel terlihat nilai tolerance lebih dari 10persen atau 0,1 dan nilai VIF kurang dari 10 yang artinya tidak ada multikolinearitas. 
Tabel 5.

Hasil Uji Heteroskedastisitas

\begin{tabular}{|c|c|c|c|c|c|}
\hline \multirow[t]{2}{*}{ Model } & \multicolumn{2}{|c|}{$\begin{array}{l}\text { Unstandardized } \\
\text { Coefficients }\end{array}$} & $\begin{array}{c}\text { Standardized } \\
\text { Coefficients }\end{array}$ & \multirow{2}{*}{$\mathbf{t}$} & \multirow{2}{*}{ Sig. } \\
\hline & B & $\begin{array}{l}\text { Std. } \\
\text { Error }\end{array}$ & Beta & & \\
\hline $\begin{array}{l}\text { (Constant) } \\
\text { Ukuran }\end{array}$ & 0,496 & 0,465 & & 1,069 & 0,295 \\
\hline $\begin{array}{l}\text { Perusahaan } \\
\text { Tangibility }\end{array}$ & $-0,027$ & 0,029 & $-0,245$ & -0936 & 0,358 \\
\hline $\begin{array}{l}\text { Assets } \\
\text { Kepemilikan }\end{array}$ & 0,075 & 0,229 & 0,088 & 0,328 & 0,746 \\
\hline Manajerial & 0,704 & 0,687 & 0,216 & 1,025 & 0,315 \\
\hline
\end{tabular}

Sumber: Data diolah, 2018

Nilai Sig. dari variabel ukuran perusahaan sebesar 0,358, variabel tangibility assets sebesar 0,746, dan variabel kepemilikan manajerial sebesar 0,315. Nilai tersebut lebih besar dari 0,05 yang artinya model yang dibuat tidak mengandung gejala heteroskedastisitas.

Tabel 6.

Hasil Uji Autokorelasi

\begin{tabular}{crrrrr}
\hline Model & R & R Square & $\begin{array}{c}\text { Adjusted R } \\
\text { Square }\end{array}$ & $\begin{array}{c}\text { Std. Error of the } \\
\text { Estimate }\end{array}$ & $\begin{array}{c}\text { Durbin- } \\
\text { Watson }\end{array}$ \\
\hline 1 & 0,896 & 0,802 & 0,779 & 0,152332415 & 2,297 \\
\hline Sumber: Data diolah, 2018 & & &
\end{tabular}

Nilai Durbin-Watson adalah sebesar 2,297. Pada tabel Durbin-Watson dengan signifikansi 5persen, dimana jumlah observasi (n) adalah 30 dan jumlah variabel independen $(\mathrm{k})$ adalah 3 maka diperoleh nilai $\mathrm{dl}=1,2138 \mathrm{dan} \mathrm{du}=$ 1,6498. Ini berarti nilai $\mathrm{du}<\mathrm{DW}<(4-\mathrm{du})$, dimana 4-du $=2,3502$ atau dapat dinotasikan juga sebagai berikut 1,6498 <2,297 <2,3502. Kesimpulannya adalah 
model regresi tidak mengandung autokorelasi karena nilai DW terletak diantara du dan (4-du).

Pada penelitian ini menggunakan standardized beta dalam interpretasi persamaan regresi linear berganda karena ukuran atau satuan variabel independen tidak sama (Ghozali, 2005:88). Satuan yang digunakan pada penelitian ini adalah persen dan rupiah.

Hasil yang diperoleh dari pengolahan data pada tabel 7 sebagai berikut.

$\mathrm{Y}=1,020 \mathrm{X}_{1}+1,299 \mathrm{X}_{2}-0,520 \mathrm{X}_{3}$

Persamaan regresi ini memiliki arti sebagai berikut.

Nilai koefisien regresi dari $\mathrm{X}_{1}$ sebesar 1,020 yang artinya terdapat hubungan yang searah antara ukuran perusahaan dengan struktur modal. Jika ukuran perusahaan meningkat sebanyak 1 satuan maka struktur modal akan meningkat pula sebesar Rp 1,020 dengan asumsi variabel lainnya konstan.

Tabel 7. Hasil Analisis Regresi Linear Berganda

\begin{tabular}{|c|c|c|c|c|c|}
\hline \multirow[t]{2}{*}{ Model } & \multicolumn{2}{|c|}{$\begin{array}{l}\text { Unstandardized } \\
\text { Coefficients }\end{array}$} & \multirow{2}{*}{$\begin{array}{r}\text { Standardized } \\
\text { Coefficients } \\
\text { Beta }\end{array}$} & \multirow[t]{2}{*}{$\mathbf{t}$} & \multirow[t]{2}{*}{ Sig } \\
\hline & B & Std. Error & & & \\
\hline (Constant) & 7454 & 0905 & & 8235 & $\begin{array}{l}0,0 \\
00\end{array}$ \\
\hline Ukuran & 0,4 & & & 8,13 & 0,0 \\
\hline Perusahaan & 62 & 0,057 & 1,020 & 7 & 00 \\
\hline Tangibility & 4,5 & & & 10,1 & 0,0 \\
\hline Assets & 40 & 0,446 & 1,299 & 72 & 00 \\
\hline Kepemilikan & & & & 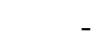 & 0,0 \\
\hline Manajerial & 6,903 & 1,338 & $-0,520$ & 5,158 & 00 \\
\hline
\end{tabular}

Nilai koefisien regresi dari $\mathrm{X}_{2}$ sebesar 1,299 yang berarti terdapat hubungan yang searah antara tangibility assets dengan stuktur modal. Jika tangibility assets 
meningkat sebanyak 1 satuan maka struktur modal juga akan meningkat sebesar 1,299persen dengan asumsi variabel lainnya konstan.

Nilai koefisien regresi dari $X_{3}$ sebesar -0,520. Nilai negatif ini berarti terdapat hubungan berlawanan antara kepemilikan manajerial dengan struktur modal. Jika kepemilikan manajerial meningkat sebanyak 1 satuan maka struktur modal akan turun sebanyak 0,520persen dengan asumsi variabel lainnya konstan.

Tabel 8.

Hasil Uji Koefisien Determinasi $\left(\mathbf{R}^{2}\right)$

\begin{tabular}{crrcc}
\hline Model & R & R Square & Adjusted R Square & $\begin{array}{c}\text { Std. Error of the } \\
\text { Estimate }\end{array}$ \\
\hline 1 & 0, & 0,802 & 0,779 & 0,152332415 \\
\hline
\end{tabular}

Sumber: Data diolah, 2018

Nilai koefisien determinasi adalah sebesar 0,802 yang berarti bahwa sebesar 0,802 satuan variasi struktur modal yang diproksikan dengan LTDER dipengaruhi oleh variasi ukuran perusahaan, tangibility assets, dan kepemilikan manajerial. Sedangkan sisanya sebesar 0,198 satuan dijelaskan oleh faktor lain yang tidak dimasukkan ke dalam model.

Uji ini menggunakan uji satu sisi karena pada hipotesis sudah tertera jelas arah penelitiannya dengan tingkat signifikansi 5persen atau 0,05 .

Tabel 9.

\begin{tabular}{lllllll}
\multicolumn{1}{c}{ Model } & & Sum of & & Mean & F & Sig. \\
& & Squares & Df & Square & & \\
\hline 1 & Regression & 2,443 & 3 & 0,814 & 35,088 & 0,000 (a) \\
& Residual & 0,603 & 26 & 0,023 & & \\
& Total & 3,046 & 29 & & & \\
& & & & & & \\
\end{tabular}

Sumber: Data diolah, 2018 
Hasil uji kelayakan model pada Tabel 8 terlihat bahwa ukuran perusahaan, tangibility assets, kepemilikan manajerial secara signifikan berpengaruh terhadap struktur modal, dimana signifikansi $\mathrm{F}$ sebesar $0,000<0,05$ dan nilai $\mathrm{F}_{\text {hitung }}>\mathrm{F}_{\text {tabel }}$ $=35,088>2,98$ sehingga dapat disimpulkan bahwa variabel bebas secara signifikan mempengaruhi variabel terikat dan model dari penelitian ini dikatakan layal untuk diteliti serta pembuktian hipotesis dapat dilanjutkan.

Berdasarkan hasil analisis uji t yang disajikan pada Tabel 7 terlihat bahwa pengaruh ukuran perusahaan terhadap struktur modal diperoleh nilai Sig. sebesar 0,000 dengan nilai koefisien beta sebesar 1,020. Nilai signifikan ukuran perusahaan sebesar $0,000<0,05$ dan $\mathrm{t}_{\text {hitung }}=8,137>\mathrm{t}_{\text {tabel }}=1,706$ maka, $\mathrm{H}_{0}$ ditolak dan $\mathrm{H}_{1}$ diterima. Ini mengindikasikan bahwa variabel ukuran perusahaan berpengaruh signifikan terhadap variabel struktur modal pada perusahaan sub sektor ritel di BEI periode 2013-2017. Nilai koefisien dan t menunjukkan arah yang positif, yang artinya apabila ukuran perusahaan meningkat, maka struktur modal akan mengalami peningkatan pula. Berdasarkan interpretasi tersebut, hipotesis pertama pada penelitian ini yaitu "ukuran perusahaan berpengaruh positif dan signifikan terhadap struktur modal" dapat diterima.

Berdasarkan hasil analisis uji t yang disajikan pada Tabel 7 terlihat bahwa pengaruh tangibility assets terhadap struktur modal diperoleh nilai Sig. sebesar 0,000 dengan nilai koefisien beta sebesar 1,299. Nilai signifikan tangibility assets sebesar $0,000<0,05$ dan $\mathrm{t}_{\text {hitung }}=10,172>\mathrm{t}_{\text {tabel }}=1,706$ yang berarti $\mathrm{H}_{0}$ ditolak dan $\mathrm{H}_{1}$ diterima, maka variabel tangibility assets berpengaruh signifikan terhadap struktur modal pada perusahaan sub sektor ritel di BEI periode 2013-2017. Nilai 
koefisien dan $\mathrm{t}$ menunjukkan arah yang positif, yang berarti apabila tangibility assets meningkat, maka struktur modal perusahaan akan meningkat pula. Berdasarkan interpretasi tersebut, hipotesis kedua pada penelitian ini yaitu "tangibility assets berpengaruh positif dan signifikan terhadap struktur modal" dapat diterima.

Berdasarkan hasil analisis uji t yang disajikan pada Tabel 7 terlihat bahwa pengaruh kepemilikan manajerialterhadap struktur modal diperoleh nilai Sig. sebesar 0,000 dengan nilai koefisien beta sebesar -0,520. Nilai signifikan kepemilikan manajerialsebesar $0,000<0,05$ dan $\mathrm{t}_{\text {hitung }}=5,158>\mathrm{t}_{\text {tabel }}=1,706$ yang berarti $\mathrm{H}_{0}$ ditolak dan $\mathrm{H}_{1}$ diterima, maka variabel kepemilikan manajerialberpengaruh signifikan terhadap struktur modal pada perusahaan sub sektor ritel di BEI periode 2013-2017. Nilai koefisen dan t menunjukkan arah yang negatif, yang berarti apabila kepemilikan manajerial meningkat, maka struktur modal perusahaan mengalami penurunan. Berdasarkan interpretasi tersebut, hipotesis ketiga pada penelitian ini yaitu "kepemilikan manajerial berpengaruh negatif dan signifikan terhadap struktur modal" dapat diterima.

Berdasarkan hasil uji atas hipotesis pertama, maka diperoleh bahwa ukuran perusahaan memiliki pengaruh positif dan signifikan terhadap struktur modal. Hal ini terlihat pada Tabel 7 dimana nilai koefisien beta sebesar 1,020 menunjukkan arah yang positif yaitu dan Sig. $0,000<0,05$. Dimana hasil ini menunjukkan bahwa pada perusahaan sub sektor ritel di BEI semakin besar ukuran perusahaan, maka perusahaan cenderung memiliki tingkat penggunaan utang yang tinggi pula. Perusahaan besar cenderung memiliki biaya utang yang lebih rendah. Biaya utang 
yang relatif rendah akan menyebabkan perusahaan besar terdorong untuk menggunakan utang yang lebih besar lagi. Hasil penelitian ini konsisten dengan hasil penelitian sebelumnya yang dilakukan oleh M'ng et al. (2017), Abdulla (2017), Shahar et al. (2016),Wasim et al. (2016), Alipour et al.(2015), Awan (2014), Dewi dan Badjra (2014), Yousefzadeh (2014), Indrajaya dkk. (2011), serta Sheikh dan Wang (2011).

Berdasarkan hasil uji atas hipotesis kedua, maka diperoleh bahwa tangibility assets memiliki pengaruh positif dan signifikan terhadap struktur modal. Hal ini terlihat pada Tabel 7 dimana nilai koefisien beta sebesar 1,299 menunjukkan arah yang positif dan Sig. $0,000<0,05$. Dimana hasil ini menunjukkan bahwa pada perusahaan sub sektor ritel di BEI semakin besar tangibility assets yang dimiliki oleh perusahaan, makasemakin besar pinjaman yang dapat diperoleh oleh perusahaan atas jaminan yang diberikan kepada kreditur. Hasil penelitian terbaru dari Tijow dkk. (2018) juga mendukung penelitian ini dimana semakin besar aktiva tetap maka kemampuan perusahaan dalam memberikan jaminan akan lebih tinggi, sehingga perusahaan akan meningkatkan hutang untuk mendapatkan keuntungan yang lebih. Hasil ini konsisten dengan hasil penelitian sebelumnya yang dilakukan oleh Abdulla (2017), Shahar et al. (2016), Wellalage dan Locke (2015), Dewi dan Badjra (2014), Wijaya dan Utama (2014), sertaRamaratnam dan Jayaraman (2013).

Berdasarkan hasil uji atas hipotesis ketiga, maka diperoleh bahwa kepemilikan manajerial memiliki pengaruh negatif dan signifikan terhadap struktur modal. Hal ini dapat terlihat pada Tabel 7 dimana nilai koefisien beta 
menunjukkan arah yang negatif yaitu $-0,520$ dan Sig. $0,000<0,05$. Dimana hasil ini menunjukkan bahwa pada perusahaan sub sektor ritel di BEI ketika kepemilikan manjerial naik, maka struktur modal perusahaan akan menurun. Hasil penelitian ini mengindikasikan bahwa perusahaan yang sebagian sahamnya dimiliki oleh manajemen memiliki kecenderungan menerapkan kebijakan hutang yang kecil. Menurut Primadhanny (2016) alasan kepemilikan saham manajemen mempunyai pengaruh yang negatif terhadap struktur modal karena dengan adanya kepemilikan saham oleh manajemen terdapat kecenderungan akan berhati-hati dalam menggunakan kebijakan hutang, sehingga meningkatnya kepemilikan saham oleh manajemen akan menurunkan jumlah hutang. Penelitian ini konsisten dengan hasil penelitian sebelumnya yang dilakukan oleh Munandar (2017),Siromi dan Chandrapala (2017), dan Wellalage dan Locke (2015).

\section{SIMPULAN DAN SARAN}

Simpulan dari hasil penelitian dan pembahasan yang telah dilakukan mengenai pengaruh ukuran perusahaan, tangibility assets, dan kepemilikan manajerial terhadap struktur modal adalah: Ukuran perusahaan berpengaruh positif dan signifikan terhadap struktur modal pada perusahaan sub sektor ritel yang terdaftar di BEI periode 2013-2017, tangibility assets berpengaruh positif dan signifikan terhadap struktur modal pada perusahaan sub sektor ritel yang terdaftar di BEI periode 2013-2017, Kepemilikan manajerial berpengaruh negatif dan signifikan terhadap struktur modal pada perusahaan sub sektor ritel yang terdaftar di BEI periode 2013-2017. 
Berdasarkan hasil penelitian yang telah dilakukan diharapkan mampu memberikan gambaran mengenai ukuran perusahaan, tangibility assets, dan kepemilikan manajerial terhadap struktur modal. Saran yang dapat diberikan adalah sebagai berikut.

Pihak manajemen dalam menentukan keputusan pendanaan terutama dalam hal struktur modal diharapkan mempertimbangkan mengenai faktor ukuran perusahaan, tangibility assets, dan kepemilikan manajerial sehingga keputusan yang diambil sesuai dengan tujuan perusahaan dan mampu meningkatkan keuntungan bagi perusahaan.

Investor dalam memutuskan untuk melakukan investasi pada suatu perusahaan diharapkan mempertimbangkan ukuran perusahaan, tangibility assets, dan kepemilikan manajerial dari perusahaan karena faktor ini yang secara signifikan mempengaruhi struktur modal sehingga nantinya tingkat keuntungan yang diterima oleh investor sesuai dengan investasi yang dilakukan pada perusahaan.

Penelitan selanjutnya diharapkan dapat mempertimbangkan variabel lain seperti peluang pertumbuhan penjualan, likuiditas, kepemilikan institusional dan sebagainya serta lingkup subjek penelitian yang lebih luas.

Keterbatasan penelitian ini adalah jumlah sampel yang hanya 6 karena pada perusahaan sub sektor Ritel yang terdaftar di BEI lebih banyak menggunakan kepemilikan institusional sehingga tidak dapat memenuhi persyaratan sebagai sampel pada penelitian ini yang memerlukan data kepemilikan manajerial.

\section{REFRENSI}


Abdulla, Yomna. (2017). Capital Structure in A Tax-free Economy: Evidencefrom UAE.www.emeraldinsight.com/1753-8394.htm. 10(1),102-116.

Alipour, Mohammad, Mir Farhad Seddigh Mohammadi, dan Hojjatollah Derakhshan.(2015). Determinants of Capital Structure: An EmpiricalStudy of Firms inIran.www.emeraldinsight.com/1754-243X.htm. 57(1),53-83.

Andrayani, Devi dan Surya Negara Sudirman. (2014). Pengaruh Pertumbuhan Penjualan,Ukuran Perusahaan Dan Tangibility Assets Terhadap Struktur Modal.E-JurnalManajemen Universitas Udayana. 3(5), 1197-1210.

Awan,Abdul Ghafoor. (2014). Determinants of Capital Structure. European Journal ofAccounting Auditing dan Finance Research. 2(9), 22-41.

Brigham, Eugene F., dan Joel F. Houston. (2011). Dasar-Dasar Manajemen Keuangan.Jakarta: Salemba Empat.

Dewi, Sugiani M. dan Badjra. (2014). Pengaruh Likuiditas, Profitabilitas, Tangibility Assets, Ukuran Perusahaan Dan Pajak Terhadap Struktur Modal. E-Jurnal Manajemen Universitas Udayana. 3(10), 3017-3033.

Dewi, S. Christianty. (2008). Pengaruh Kepemilikan Manajerial, Kepemilikan Institusional, Kebijakan Utang, Profitabilitas, dan Ukuran Perusahaan TerhadapKebijakan Deviden. Jurnal Bisnis dan Akuntansi. 10(1),47-58.

Fahmi, Irham. (2016). Pengantar Manajemen Keuangan Teori Dan Soal Jawab. Bandung: Alfabeta.

Farooque, Omar Al, Tony van Zijl, Keitha D., dan AKM Waresul K. (2007). Corporate Governance in Bangladesh: Link between Ownershipand Financial Performance,Blackwell Publishing Ltd. Journal Compilation. 15(6), 1453-1468.

Husnan, Suad. (2013). Manajemen Keuangan Teori Dan Penerapan (Keputusan JangkaPanjang). Edisi 4. Yogyakarta: BPFE.

Indonesia Stock Exchange. (2018). IDX. Diunduh dari Laporan Keuangan \& Tahunan website: https://www.idx.co.id.

Indrajaya, Glenn, Herlina, dan Rini Setiadi. (2011). Pengaruh Struktur Aktiva, UkuranPerusahaan, Tingkat Pertumbuhan, Profitabilitas dan Risiko Bisnis TerhadapStruktur Modal: Studi Empiris Pada Perusahaan Sektor Pertambangan yangListing di Bursa Efek Indonesia Periode 2004-2007. Akurat Jurnal Ilmiah AkuntansiNomor 6.

Kamaludin dan Rini Indriani. (2012). Manajemen Keuangan: Konsep Dasar dan 
Penerapannya. Edisi Revisi. Bandung: CV Mandar Maju.

Malinić, Dejan, Ksenija Denčić Mihajlov, dan Ema Ljubenović. (2013). The Determinants of Capital Structure in Emerging Capital Markets: Evidence from Serbia. European ResearchStudies. 16(2), 98-119.

Manopo, Widy F. (2013). Faktor-Faktor Yang Mempengaruhi Struktur Modal PerbankanYang Go Public Di Bei Tahun 2008-2010. Jurnal EMBA. 1(3), 653-663.

Munandar, Agus. (2017). The Impact of Managerial Ownership, Size, dan Growth Rate onCapital Structure. Jurnal Riset Terapan Akuntansi. 1(2), 84-88.

Musthafa H. (2017). Manajemen Keuangan. Yogyakarta: ANDI.

M'ng, Jacinta Chan Phooi, Mahfuzur Rahman, dan Selvam Sannacy. (2017). The Determinants of Capital Structure: Evidence from Public Listed Companies

in Malaysia, Singapore and Thailand. 1-34.

https://doi.org/10.1080/23322039.2017.1418609.

Portell, Greg \& Mirko Warschun. (2017). ATKearney. Diunduh dari Global Retail Development Index, The Age of Focus website: https://www.atkearney.com/global-retail-development-index/rankings.

Primadhanny, Risty. (2016). Pengaruh Struktur Kepemilikan Terhadap Struktur ModalPada Perusahaan Sub sektor Pertambangan yang Tercatat di BEI Periode 2010-2014. Jurnal Ilmu Manajemen. 4(3), 3-9.

Ramaratnam, M.S., dan R. Jayaraman. (2013). Determinants of Capital Structure WithSpecial Reference to Indian Pharmaceutical Sector: Panel Data Analysis.Journalof Commercedan Accounting Research. 2(4), 45-50.

SahamOK. (2017). Sub Sektor Perdagangan Eceran BEI website: https://www.sahamok.com/emiten/sektor-perdagangan-jasa-investasi/subsektor-perdagangan-eceran/amp/.

Shahar, Hanita Kadir, Azira Abdul Adzis, dan Nureliana Baderi. (2016). The Relationshipbetween Ownership Structure, Firm Specific Characteristics and Capital Structure:Evidence from Malaysian Middle-capital Public Listed Firms. International Journal of Economics danFinancial Issues. 6(S3), 36-43.

Sheikh, Nadeem Ahmed, dan Zongjun Wang. (2011). Determinants of Capital StructureAn Empirical Study of Firms in Manufacturing Industry of Pakistan. www.emeraldinsight.com/0307-4358.htm. 37(2), 117-133. 
Siromi,Bulathsinhalage, dan Pathirawasam Chandrapala. (2017). The Effect of CorporateGovernance on Firms' Capital Structure of Listed Companies in Sri Lanka. Journalof Competitiveness. 9(2), 19-33.

Sulindawati, Erni, Yuniarta, dan Purnamawati. (2017). Manajemen Keuangan: Sebagai Dasar Pengambilan Keputusan Bisnis. Depok: Rajawali Pers.

Sugiyono. (2017). Metode Penelitian \& Pengembangan. Bandung: Alfabeta.

Tijow, Anggelita P., Harijanto Sabijono, dan Victorina Z. Tirayoh. (2018). PengaruhStruktur Aktiva Dan Profitabilitas Terhadap Struktur ModalPada PerusahaanSektor Industri Barang Konsumsi Yang Terdaftar DiBursa Efek Indonesia. Jurnal Riset Akuntansi Going Concern. 13(3), 477-488.

Wahidahwati. (2002). Kepemilikan Manajerial dan Agency Conflicts: Analisis Persamaan Simultan Non Linier dari Kepemilikan Manajerial, Penerimaan Risiko (Risk Taking), Kebijakan Utang, Dan Kebijakan Dividen. Jurnal dan Prosiding SNA. 7(2), 105-126.

Wasim, S.M. Shoab, Sadaf Alam, Maria Saeed. (2016). An Empirical Analysis of CapitalStructure of KSE-100 Listed Electricity Companies of Pakistan. 6(1), 101-114.

Wellalage, Nirosha Hewa dan Stuart Locke.(2015). Impact of Ownership Structure

OnCapital Structure of New Zealdan Unlisted Firms. www.emeraldinsight.com/14626004.htm. 22(1), 127-142.

Wiagustini. (2014). Manajemen Keuangan. Denpasar: Udayana University Press.

Wijaya, Andre Sucita dan Karya Utama. (2014). Pengaruh Profitabilitas, Struktur Aset,Dan Pertumbuhan Penjualan Terhadap Struktur Modal Serta Harga Saham. E-Jurnal Akuntansi Universitas Udayana. 6(3). 514-530.

Wiyadi, Rina Trisnawati, Noer Sasongko, dan Ichwani Fauzi. (2015). The Effect OfInformation Asymmetry, Firm Size, Leverage, Profitability And Employee StockOwnership On Earnings Management With Accrual 30. Model. International Journalof Business, Economics and Law. 8(2). 21-

Wiyono, Gendro, dan Hadri Kusuma. (2017). Manajemen Keuangan Lanjutan. Yogyakarta: UPP STIM YKPN.

Yarram, Subba Reddy. (2013). Ownership dan Financial Leverage: Australian Evidence. Asia Pacific Journal of Economics \& Business. 17(1\&2), 13-23. 
Ni Kadek Arie Oktaviantari, Pengaruh Ukuran Perusahaan...

Yousefzadeh, Nasrin, Zeinab Aazami, Hilda Shamsadini, Mina Abousaiedi. (2014).

Determinants of Capital Structure of Iranian Companies Listed inTehran

Stock Exchange: A Structural Equation Modeling Approach.

IndianJournal

OfCommerce \& Management Studies. 5(2), 73-81. 
E-Jurnal Manajemen, Vol. 8, No. 6, 2019 :3843-3872 